\title{
KERAGAMAN JENIS TUMBUHAN BAWAH PADA BERBAGAI TEGAKAN HUTAN TANAMAN DI BENAKAT, SUMATERA SELATAN
}

\author{
(Understorey Diversity on Several Plantation Forest Stands in Benakat, South Sumatra)
}

\author{
Adi Kunarso dan/and Fatahul Azwar \\ Balai Penelitian Kehutanan Palembang \\ Jl. Kol H Burlian Km 6,5 Punti Kayu Palembang Kotak Pos 179 \\ Telp/Fax.(0711) 414864
}

Naskah masuk : 31 Juli 2012; Naskah diterima : 20 Mei 2013

\begin{abstract}
Research in understorey diversity on several stands of plantation forests has been conducted in Benakat, South Sumatra. This research was intended to know the composition and diversity of understorey of 4 (four) planted species (Swietenia machropylla, Pinus merkusii, Peronema canescens, and Schima walichii). Twenty vegetation plots ( $2 m x$ $2 \mathrm{~m})$ were sampled in each stand by means of purposive sampling method. The highest diversity of understorey was recorded in Swietenia machropylla stand, while the lowest diversity was documented in Schima walichii stand. Different species on plantation forest affects the structure, dominancy, and diversity of understorey. The understorey diversity does not indicate significant correlation with soil parameters, however the abundance of Chromolaena odorata and Imperata cylindrica has potencyas C-Organic and $N$-Totalindicator.
\end{abstract}

Keywords: Plantation forest, species diversity, understorey

\begin{abstract}
ABSTRAK
Penelitian keragaman jenis tumbuhan bawah pada beberapa tegakan hutan tanaman telah dilakukan di Benakat, Sumatera Selatan. Penelitian ini bertujuan untuk mengetahui komposisi dan keragaman jenis tumbuhan bawah pada 4 (empat) jenis tegakan hutan tanaman, yaitu mahoni (Swietenia macrophylla), pinus (Pinus merkusii), sungkai (Peronema canescens, dan seru (Schima wallichii). Pengambilan data menggunakan metode purposive sampling sebanyak 20 petak contoh per jenis tegakan, dengan ukuran $2 \mathrm{~m} \times 2 \mathrm{~m}$. Keragaman jenis tumbuhan bawah tertinggi pada tegakan mahoni, sedangkan terendah pada tegakan seru. Perbedaan jenis tanaman pokok mempengaruhi struktur, dominasi dan keragaman jenis tumbuhan bawah. Keragaman jenis tumbuhan bawah tidak menunjukkan adanya hubungan yang nyata dengan paramater kualitas tanah, namun demikian kelimpahan katoman (Chromolaena odorata) dan alang-alang (Imperata cylindrica) berpotensi untuk dijadikan indikator terhadap kandungan C-Organik dan N-Total.
\end{abstract}

Kata kunci : Hutan tanaman, keragaman jenis, tumbuhan bawah

\section{PENDAhULUAN}

Pembangunan hutan tanaman bertujuan untuk meningkatkan produktivitas lahan yang kurang produktif, meningkatkan kualitas lingkungan hidup serta menjamin tersedianya secara lestari bahan baku industri. Jenis pohon yang dikembangkan pada hutan tanaman secara garis besar dibagi menjadi tiga kelompok, yaitu (1) kelompok kayu pertukangan misalnya meranti (Shorea spp.), jati (Tectona grandis) dan mahoni (Swietenia spp.), (2) kelompok kayu untuk pulp/serat misalnya akasia (Acacia mangium, A. crassicarpa) dan ekaliptus (Eucalyptus spp.), dan (3) kelompok kayu energi misalnya weru (Albizia procera), pilang (Acacia leucophloa), akor (A. auriculiformis), dan kaliandra (Calliandra calothyrsus).

Dalam konteks pembangunan hutan tanaman skala luas, komunitas tumbuhan bawah pada hutan tanaman selalu identik dengan gulma yang sejak dahulu dipandang sebagai tanaman pengganggu dan merugikan. Namun demikian apabila dilihat dari perspektif yang lain, keberadaan komunitas tumbuhan bawah pada hutan tanaman merupakan komponen keanekaragaman hayati yang sangat penting untuk dilestarikan, karena mempunyai beberapa nilai yaitu: nilai eksistensi, etika, estetika dan manfaat psikologis, nilai jasa 
lingkungan, nilai warisan, nilai pilihan, nilai konsumtif dan nilai produktif (Djarwaningsih, 2010). Nilai pilihan merupakan keterkaitan dengan potensi dalam memberikan keuntungan dimasa datang, kepunahannya merupakan nilai kerugian bagi kesejahteraan manusia, seperti misalnya potensi tumbuhan liar yang berpotensi sebagai sumber obat-obatan dan koleksi plasma nutfah sebagai sumber pemuliaan tanaman.

Soerianegara dan Indrawan (1998) memberikan batasan mengenai vegetasi tumbuhan bawah, yaitu semua vegetasi yang bukan pohon dan tidak dapat tumbuh menjadi tingkat pohon. Kehadiran tumbuhan bawah pada hutan tanaman selain sebagai sumber keragaman hayati juga berperan untuk melindungi tanah dan organisme tanah, membantu menciptakan iklim mikro di lantai hutan, menjaga tanah dari bahaya erosi, serta dapat memelihara kesuburan tanah. Erosi permukaan yang berlangsung terus menerus akan menghanyutkan unsur hara pada lapisan tanah atas, sehingga mengakibatkan hilangnya kesuburan tanah pada suatu tegakan hutan tanaman. Asdak (2002) mengungkapkan bahwa penghilangan tumbuhan bawah dan seresah dalam pengelolaan hutan tanaman dan kebun campuran dapat meningkatkan besarnya erosi dan aliran permukaan. Sementara Sarief (1986) dalam Sumiyarso (1995), mengemukakan bahwa besarnya erosi padatanah latosol di Bogor, dengan kemiringan 35\% dan ditumbuhi pohon dan semak dibawahnya adalah sebesar 0,035 ton/ha/tahun, sedangkan pada tanah yang ditumbuhi pohon tanpa semak dibawahnya sebesar 13,20 ton/ha/ tahun. Disamping itu keberadaan tumbuhan bawah dapat digunakan untuk menggambarkan keadaan tanah yang dapat dilihat secara nyata di lapangan, sebelum dilakukan analisis laboratorium (Hartanto, 1990 dalam Sumiyarso, 1995). Menurut Akbar et al., (2005), keberadaan tumbuhan bawah pada areal bekas tambang batubara dapat meningkatkan kestabilan tanah, kesuburan tanah dan meningkatkan produktivitas lahan kritis menuju aslinya.

Dari uraian tersebut diatas diketahui bahwa tumbuhan bawah mempunyai peranan yang penting sebagai bagian dari keanekaragaman hayati dan dalam pengendalian laju erosi. Namun demikian informasi mengenai keanekaragaman jenis tumbuhan bawah pada hutan tanaman, khususnya data kuantitatif masih sangat sedikit. Oleh karena itu perlu dilakukan penelitian untuk mengetahui komposisi dan keragaman jenis tumbuhan bawah pada beberapa jenis tegakan hutan tanaman peng- hasil kayu pertukangan seperti mahoni, pinus, sungkai, dan seru.

\section{METODE PENELITIAN}

\section{A. Lokasi Penelitian}

Penelitian dilakukan di Kawasan Hutan Dengan Tujuan Khusus (KHDTK) Benakat, yang secara administratif terletak di Desa Sungai Baung, Kecamatan Talang Ubi, Kabupaten Muara Enim (Gambar 1). Jenis tanah di lokasi penelitian didominasi Podsolik Merah Kuning (PMK), dengan topografi bergelombang (kemiringan lereng 8 $15 \%$ ). Curah hujan rata-rata tahunan $1.800-$ $2.000 \mathrm{~mm}$ dengan tipe iklim A menurut klasifikasi Schmidt dan Ferguson (1951).

Sejarah pengelolaan hutan Benakat ditandai dengan dimulainya kerjasama antara Pemerintah Indonesia dengan Japan International Cooperation Agency (JICA) melalui Proyek ATA 186 tentang penanaman di lahan alang-alang atau yang juga dikenal dengan sebutan The Trial Plantation Project in Benakat South Sumatra (ATA 186). Lokasi tersebut saat ini ditetapkan oleh Kementerian Kehutanan RI menjadi Kawasan Hutan Dengan Tujuan Khusus (KHDTK)/ Hutan Penelitian Benakat, melalui SK No.111/ Menhut-II/2004 seluas 3.900 ha. Kawasan HP Benakat berbatasan langsung dengan areal konsesi Hutan Tanaman Industri (HTI) PT. Musi Hutan Persada (PT. MHP), yang memiliki areal pengelolaan di wilayah Benakat seluas 198.741 ha dari luas total areal 296.400 ha. Jenis-jenis tanaman penyusun HP Benakat antara lain: akasia (Acacia mangium), mahoni (Swietenia macrophylla),pinus (Pinus merkusii), gmelina (Gmelina arborea), seru (Schima wallichii), kayu putih (Melaluca cajuputi), sungkai (Peronema canescens) dan lain-lain.

\section{B. Rancangan Penelitian}

Pengambilan data dilakukan pada hutan tanaman jenis mahoni, pinus, sungkai dan seru di Blok I KHDTK Benakat pada luasan 50 ha, masing-masing berumur 25 tahun (tahun tanam 1982) dan jarak tanam $4 \mathrm{~m} \times 2 \mathrm{~m}$. Metode yang digunakan adalah purposive sampling dengan jumlah petak contoh sebanyak 20 petak per jenis tegakan. Ukuran masing-masing petak contoh 2 m x 2 m (Indriyanto, 2006). Respon yang diamati adalah kerapatan, frekuensi, indeks nilai 




Gambar (Figure)1. Peta lokasi penelitian (Map of research location)

penting, kesamaan komunitas, dan indeks keragaman jenis tumbuhan bawah. Herbarium dibuat untuk mengidentifikasi tumbuhan yang belum diketahui jenisnya, untuk selanjutnya didentifikasi di Herbarium Bogoriense, Lembaga Ilmu Pengetahun Indonesia (LIPI).

Pengamatan kondisi lingkungan dilakukan melalui pengambilan data kondisi tanah, suhu, kelembaban udara, dan intensitas cahaya. Pengambilan contoh tanah dilakukan di dalam petak pengamatan tumbuhan bawah dengan ke dalaman $0-20 \mathrm{~cm}$. Sampel tanah merupakan campuran (komposit) dari 3 (tiga) titik pengambilan tanah di tiap jenis tegakan. Sampel tanah dianalisis di Laboratorium Ilmu Tanah Universitas Sriwijaya. Pengamatan suhu, kelembaban, dan intensitas cahaya dilakukan pada periode yang sama dengan pengambilan data tumbuhan yaitu antara pukul 10.00 sampai 15.00 WIB.

\section{C.Analisis Data}

1. Kerapatan, frekuensi, dan Indeks Nilai Penting (INP) tiap jenis tumbuhan bawah

$$
\begin{aligned}
& \text { Kerapatan }(K) \quad=\frac{\sum \text { individu }}{\text { luas petak contoh }} \ldots \ldots \ldots \ldots . . . \ldots \\
& \text { Kerapatan relatif }(K R)=\frac{K \text { suatu jenis }}{K \text { total seluruh jenis }} \times 100 \% \ldots \\
& \text { Frekuensi }(F)=\frac{\sum \text { subpetak ditemukan suatu species }}{\sum \text { seluruh subpetak contoh ... }} \\
& \text { Frekuensi relatif }(F R)=\frac{F \text { suatu jenis }}{F \text { total seluruh jenis }} \times 100 \% \ldots \\
& \text { Indeks Nilai Penting }(I N P)=K R+F R \text {.................. }
\end{aligned}
$$

2. Indeks kesamaan komunitas tumbuhan bawah Untuk mengetahui tingkat kesamaan komunitas tumbuhan bawah pada beberapa jenis tegakan hutan tanaman dipergunakan rumus sebagai berikut (Odum, 1971).

$I S=\frac{2 C}{A+B}$

Keterangan:

IS $=$ indeks kesamaan

$\mathrm{C}=$ jumlah spesies yang sama dan terdapat pada kedua komunitas

$\mathrm{A}=$ jumlah spesies di dalam komunitas $\mathrm{A}$

$\mathrm{B}=$ jumlah spesies di dalam komunitas $\mathrm{B}$ 
3. Indeks keragaman jenis tumbuhan bawah Untuk memperkirakan keragaman jenis tumbuhan bawah digunakan indeks keragaman Shanon-Wiener (Odum, 1971)

$H=\sum_{i=1}^{s} p_{i} \log p_{i}$

dimana,

$p_{i}=\frac{\sum n_{i}}{N}$

Keterangan :

$\mathrm{H}=$ indeks keragaman

$\mathrm{n}_{\mathrm{i}}=$ jumlah individu atau nilai penting jenis ke-i

$\mathrm{s}=$ jumlah total jenis yang ditemukan

$\mathrm{N}=$ total individu atau total nilai penting seluruh jenis

4. Untuk mengetahui hubungan keragaman jenis tumbuhan bawah dengan kualitas tanah dilakukan analisis korelasidan regresi menggunakan SPSS versi 10.0.

\section{HASIL DAN PEMBAHASAN}

\section{A. Hasil Penelitian}

\section{Kondisi tegakan}

Pertumbuhan rata-rata tegakan mahoni, pinus, sungkai dan seru pada umur 25 tahun dapat dilihat pada Tabel 1 .

Tegakan mahoni dan pinus mempunyai tutupan tajuk yang lebih rapat dan pertumbuhan yang relatif lebih cepat dibanding tegakan sungkai dan seru (Tabel 1). Lebar tajuk tegakan mahoni mencapai rata-rata 7,58 $\mathrm{m}$ atau yang tertinggi diantara tegakan yang lain, sedangkan terendah pada tegakan seru yaitu dengan lebar tajuk rata-rata 2,38 m. Hal ini diduga karena jenis mahoni dan pinus lebih adaptif dengan kondisi tanah di lokasi penelitian. Disamping itu dipengaruhi juga oleh karakteristik kedua jenis tersebut yang secara alami mempunyai rentang tajuk yang lebar.

\section{Komunitas Tumbuhan Bawah}

Hasil penelitian menunjukkan terdapat perbedaan struktur komunitas tumbuhan bawah pada tegakan mahoni dengan sungkai dan mahoni dengan seru. Namun demikian struktur komunitas tumbuhan bawah pada beberapa jenis tegakan hutan tanaman yang lain dapat dikatakan sama (Tabel 2).

Dari Tabel 2 terlihat bahwa dua jenis tegakan dengan lebar tajuk yang relatif sama cenderung menunjukkan adanya kesamaan struktur komunitas. Hal ini dapat dilihat pada tegakan sungkai dengan seru (IS $=0,71)$ dan mahoni dengan pinus (IS $=0,56$ ), dimana masing - masing mempunyai struktur komunitas tumbuhan bawah yang sama. Sebaliknya, pada dua tegakan dengan lebar tajuk yang berbeda (mahoni dengan sungkai) cenderung mempunyai struktur komunitas tumbuhan bawah yang berbeda pula (IS $=0,41$ ).

\section{Keragaman jenis tumbuhan bawah}

Secara umum keragaman jenis tumbuhan bawah pada areal penelitian tergolong rendah, dengan nilai indeks keragaman jenis $(\mathrm{H})<2(\mathrm{Gam}-$ bar 2). Namun demikian, terdapat perbedaan jumlah jenis dan keragaman jenis tumbuhan bawah pada tiap jenis tegakan hutan tanaman.

\section{Tumbuhan Bawah Dominan}

Berdasarkan nilai Indeks Nilai Penting (INP), maka jenis-jenis yang dominan pada masingmasing tegakan dapat diketahui. Pada tegakan mahoni tumbuhan bawah yang paling mendominasi yaitu lengkenai (Slaginella opaca), sedangkan pada tegakan pinus didominasi oleh rumput empritan (Cyrtococcum acrescens). Pada tegakan sungkai dan seru didominasi oleh jenis alangalang. Nilai INP untuk 5 jenis tumbuhan bawah paling dominan pada masing-masing tegakan disajikan pada Tabel 3 .

Tabel (Table) 1. Diameter, tinggi, dan lebar tajuk tegakan pada umur 25 tahun (Diameter, height, and crown width on twenty-fifth years-old of the stand)

\begin{tabular}{|c|c|c|c|c|}
\hline \multirow[b]{2}{*}{ No. } & \multirow[b]{2}{*}{$\begin{array}{c}\text { Jenis } \\
\text { (Species) }\end{array}$} & \multicolumn{3}{|c|}{ Rerata (Average) } \\
\hline & & $\begin{array}{c}\text { Diameter (Diameter) } \\
(\mathrm{cm})\end{array}$ & $\begin{array}{l}\text { Tinggi (Height) } \\
\text { (m) }\end{array}$ & $\begin{array}{c}\text { Lebar tajuk } \\
\text { (Crown width) (m) }\end{array}$ \\
\hline 1. & Mahoni (Swietenia macrophylla) & 34,41 & 25,50 & 7,58 \\
\hline 2. & Pinus (Pinus merkusii) & 36,84 & 24,50 & 5,40 \\
\hline 3. & Sungkai (Peronema canescens) & 20,19 & 19,65 & 3,22 \\
\hline 4. & Seru (Schima walichii) & 20,59 & 12,05 & 2,38 \\
\hline
\end{tabular}


Tabel(Table) 2. Indeks kesamaan komunitas tumbuhan bawah pada lokasi penelitian (Similarity index of understorey in the research location)

\begin{tabular}{clccc}
\hline $\begin{array}{c}\text { No } \\
\text { (Number) }\end{array}$ & \multicolumn{1}{c}{$\begin{array}{c}\text { Jenis } \\
\text { (Species) }\end{array}$} & $\begin{array}{c}\text { Pinus } \\
\text { (Pinus merkusii) }\end{array}$ & $\begin{array}{c}\text { Sungkai } \\
\text { (Peronema canescens) }\end{array}$ & $\begin{array}{c}\text { Seru } \\
\text { (Schima wallichii) }\end{array}$ \\
\hline 1. & Mahoni & 0,56 & 0,41 & 0,48 \\
2. & (Swietenia macrophylla) & & 0,65 & 0,70 \\
3. & $\begin{array}{l}\text { Pinus (Pinus merkusii) } \\
\text { Sungkai }\end{array}$ & & & 0,71 \\
\hline
\end{tabular}

Keterangan (Remarks): Dua komunitas yang memiliki Indeks Kesamaan Komunitas (IS) $>0,50$ dianggap sama (Two community which has community similarity index (IS) $>0.50$ are similar)

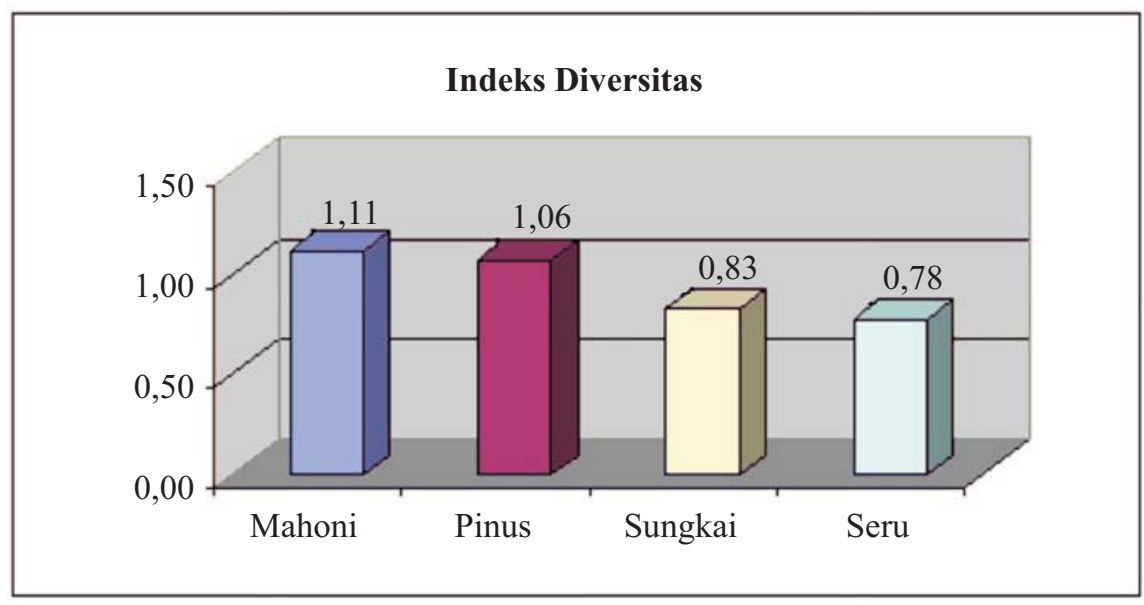

Gambar (Figure) 2. Indeks keragaman jenis tumbuhan bawah pada beberapa jenis tegakan (Understorey diversity index on several stands)

Berdasarkan besarnya Indeks Nilai Penting (INP), diketahui bahwa pada tegakan mahoni didominasi oleh jenis lengkenai dan paku hata (Lygodium circinatum Sw.) dengan nilai INP $47,46 \%$ dan $24,76 \%$, kemudian diikuti oleh jenis katoman (Chromolaena odorata L. (24,21\%) dan paku harupat (Nephrolepis biserata) (22,17\%). Pada tegakan pinus didominasi oleh jenis rumput empritan $(56,18 \%)$, katoman $(30,67 \%)$, dan diikuti jenis meniran (Phyllanthus niruri L.) $(25,12 \%)$. Sedangkan jenis alang-alang tumbuh dominan pada tegakansungkai dan seru dengan INP masing-masing sebesar $80,38 \%$ dan $98,14 \%$.

\section{Kondisi Lingkungan dan Kualitas Tanah}

Hasil pengamatan suhu, kelembaban udara dan intensitas cahaya matahari disajikan dalam Tabel 4. Sedangkan hasil analisis sifat kimia tanah disajikan pada Tabel 5.

Hasil analisis sifat kimia tanah (Tabel 5) memperlihatkan nilai $\mathrm{pH}$ tanah berkisar dari 4,22 4,46 yang berarti termasuk dalam kriteria sangat masam (Pusat Penelitian Tanah, 1982). Keter- sediaan unsur hara makro (K, $\mathrm{Na}, \mathrm{Ca}$, dan $\mathrm{Mg}$ ) di tanah termasuk kategori sangat rendah hingga rendah.Sedangkan nilai Kapasitas Tukar Kation (KTK) termasuk dalam kategori rendah hingga sedang dan kadar bahan organik (C-Organik) termasuk kategori rendah.

\section{Hubungan keragaman jenis tumbuhan bawah dengan kualitas tanah}

Hasil analisis korelasi antara keragaman jenis tumbuhan bawah dengan parameter kualitas tanah disajikan pada Tabel 6 .

\section{B. Pembahasan}

\section{Keragaman jenis tumbuhan bawah}

Berdasarkan hasil pengamatan, terlihat bahwa perbedaan jenis tanaman pokok pada hutan tanaman mempengaruhi struktur dan komposisi jenis tumbuhan bawah (Tabel 2). Hal ini terjadi karena kondisi lingkungan mikro di bawah tegakan yang berbeda akibat perbedaan tingkat naungan. Penelitian Wang et al., (2010) pada tegakan Eucalyptus juga menunjukkan hasil yang sama, 
Tabel(Table) 3. Indeks Nilai Penting (INP) tertinggi untuk 5 jenis tumbuhan bawah (The highest important value index of five understorey)

\begin{tabular}{|c|c|c|c|c|c|c|}
\hline No. & $\begin{array}{l}\text { Jenis tumbuhan bawah } \\
\text { (Undergrowth species) }\end{array}$ & $\begin{array}{c}\mathrm{KJ} \\
(\mathrm{N} / \mathrm{Ha})\end{array}$ & $\begin{array}{l}\mathrm{KR} \\
(\%)\end{array}$ & FJ & $\begin{array}{l}\text { FR } \\
(\%)\end{array}$ & $\begin{array}{l}\text { INP } \\
(\%)\end{array}$ \\
\hline I & Tegakan Mahoni (Swietenia macrophylla stand) & & & & & \\
\hline 1. & Slaginella opaca & 18,63 & 31,91 & 0,70 & 15,56 & 47,46 \\
\hline 2. & Lygodium circinatum $\mathrm{Sw}$. & 5,38 & 9,21 & 0,70 & 15,56 & 24,76 \\
\hline 3. & Chromolaena odorata L. & 7,00 & 11,99 & 0,55 & 12,22 & 24,21 \\
\hline 4. & Nephrolepis biserata & 7,75 & 13,28 & 0,40 & 8,89 & 22,17 \\
\hline 5. & Stachyphynium sp. & 7,00 & 11,99 & 0,05 & 1,11 & 13,10 \\
\hline II & Tegakan Pinus (Pinus merkusii stand) & & & & & \\
\hline 1. & Cyrtococcum acrescens (Trin) Stapf & 84,25 & 45,42 & 0,85 & 10,76 & 56,18 \\
\hline 2. & Chromolaena odorata L. & 20,50 & 11,05 & 1,55 & 19,62 & 30,67 \\
\hline 3. & Phyllanthus niruri L. & 38,38 & 20,69 & 0,35 & 4,43 & 25,12 \\
\hline 4. & Lygodium circinatum $\mathrm{Sw}$. & 7,00 & 3,77 & 1,25 & 15,82 & 19,60 \\
\hline 5. & Solanum toruum & 3,13 & 1,68 & 0,70 & 8,86 & 10,55 \\
\hline III & Tegakan Sungkai (Peronema canescens stand) & & & & & \\
\hline 1. & Imperata cylindrica $\mathrm{L}$. & 196,63 & 78,41 & 0,55 & 10,48 & 80,38 \\
\hline 2. & Cyrtococcum acrescens (Trin) Stapf & 28,75 & 11,47 & 0,75 & 14,29 & 20,99 \\
\hline 3. & Chromolaena odorata L. & 4,50 & 1,79 & 0,60 & 11,43 & 13,22 \\
\hline 4. & Lygodium circinatum $\mathrm{Sw}$. & 4,25 & 1,69 & 0,50 & 9,52 & 8,47 \\
\hline 5. & Scleria sumatrensis Retz. & 2,25 & 0,90 & 0,25 & 4,76 & 4,28 \\
\hline IV & Tegakan Seru(Schima walichii stand) & & & & & \\
\hline 1. & Imperata cylindrica (Linn) & 418,75 & 86,54 & 0,80 & 11,59 & 98,14 \\
\hline 2. & Scleria sumatrensis Retz & 20,38 & 4,21 & 0,95 & 13,77 & 17,98 \\
\hline 3. & Lygodium circinatum $\mathrm{Sw}$. & 13,88 & 2,87 & 0,80 & 11,59 & 14,46 \\
\hline 4. & Chromolaena odorata $\mathrm{L}$. & 6,75 & 1,39 & 0,90 & 13,04 & 14,44 \\
\hline 5. & Curuligo orchoides & 1,50 & 0,31 & 0,35 & 5,07 & 5,38 \\
\hline
\end{tabular}

Keterangan (Remarks) :

$\mathrm{KJ}=$ Kerapatan jenis (Species density)

$\mathrm{KR}=$ Kerapatan relatif (Relative density)

$\mathrm{FJ}=$ Frekwensi jenis (Species frequency)

$\mathrm{FR}=$ Frekwensi relatif (Relative frequency)

$\mathrm{INP}=$ Indeks Nilai Penting (importance value index)

Tabel (Table) 4. Suhu, kelembaban udara dan intensitas cahaya pada lokasi penelitian (Temperature, humidity, and light intensity in the research location)

\begin{tabular}{clccc}
\hline No & \multicolumn{1}{c}{$\begin{array}{c}\text { Jenis } \\
\text { (Species) }\end{array}$} & $\begin{array}{c}\text { Suhu } \\
(\text { Temperature }) \\
\left({ }^{\circ} \mathrm{C}\right)\end{array}$ & $\begin{array}{c}\text { Kelembaban udara } \\
\text { (Air humidity) } \\
(\%)\end{array}$ & $\begin{array}{c}\text { Intensitas Cahaya } \\
\text { (light intensity) } \\
(\%)\end{array}$ \\
\hline 1 & Swietenia macrophylla & 28,83 & 67,90 & 61,23 \\
2 & Pinus merkusii & 29,44 & 53,33 & 88,87 \\
3 & Peronema canescens & 31,05 & 52,89 & 91,76 \\
4 & Schima wallichii & 30,25 & 64,65 & 89,43 \\
\hline
\end{tabular}


Tabel (Table) 5. Sifat kimia tanah pada lokasi penelitian (Chemical soil characteristic in the research location)

\begin{tabular}{|c|c|c|c|c|c|c|c|c|c|c|c|}
\hline \multirow[t]{2}{*}{$\begin{array}{c}\text { Jenis } \\
\text { (species) }\end{array}$} & \multirow[t]{2}{*}{$\begin{array}{c}\mathrm{pH} \\
(\mathrm{H} 2 \mathrm{O})\end{array}$} & \multirow[t]{2}{*}{$\begin{array}{l}\text { C- } \\
\text { Org. } \\
(\%)\end{array}$} & \multirow[t]{2}{*}{$\begin{array}{c}\text { N-Tot } \\
(\%)\end{array}$} & \multirow[t]{2}{*}{$\begin{array}{c}\mathrm{C} / \mathrm{N} \\
\text { Ratio }\end{array}$} & \multicolumn{4}{|c|}{$\begin{array}{c}\text { Kation Dapat Ditukar } \\
\text { (me/100 g) } \\
\text { (Exchangable Cations) }\end{array}$} & \multirow{2}{*}{$\begin{array}{c}\mathrm{KTK} \\
(C E C) \\
(\mathrm{me} / \\
100 \mathrm{~g})\end{array}$} & \multirow{2}{*}{$\begin{array}{c}\text { Kej.Basa } \\
\text { (Base } \\
\text { Sat.) } \\
(\%)\end{array}$} & \multirow{2}{*}{$\begin{array}{c}\text { Kej.A } \\
(A l \\
\text { Sat. }) \\
(\%)\end{array}$} \\
\hline & & & & & K & $\mathrm{Na}$ & $\mathrm{Ca}$ & $\mathrm{Mg}$ & & & \\
\hline $\begin{array}{l}\text { Swietenia } \\
\text { macrophylla }\end{array}$ & $\begin{array}{l}4,22 \\
(\mathrm{sm})\end{array}$ & $\begin{array}{l}1,25 \\
(\mathrm{r})\end{array}$ & $\begin{array}{c}0,11 \\
(\mathrm{r})\end{array}$ & $\begin{array}{c}11,36 \\
(\mathrm{~s})\end{array}$ & $\begin{array}{c}0,13 \\
(\mathrm{r})\end{array}$ & $\begin{array}{c}0,33 \\
(\mathrm{r})\end{array}$ & $\begin{array}{l}1,28 \\
(\mathrm{sr})\end{array}$ & $\begin{array}{l}0,60 \\
(\mathrm{r})\end{array}$ & $\begin{array}{c}18,49 \\
\text { (s) }\end{array}$ & $\begin{array}{c}12,66 \\
(\mathrm{sr})\end{array}$ & $\begin{array}{c}18,93 \\
(\mathrm{r})\end{array}$ \\
\hline Pinus merkusii & $\begin{array}{l}4,27 \\
(\mathrm{sm})\end{array}$ & $\begin{array}{l}1,05 \\
(\mathrm{r})\end{array}$ & $\begin{array}{l}0,11 \\
(\mathrm{r})\end{array}$ & $\begin{array}{l}9,55 \\
(\mathrm{r})\end{array}$ & $\begin{array}{l}0,13 \\
(\mathrm{r})\end{array}$ & $\begin{array}{l}0,22 \\
(\mathrm{r})\end{array}$ & $\begin{array}{l}1,18 \\
(\mathrm{sr})\end{array}$ & $\begin{array}{l}0,41 \\
(\mathrm{r})\end{array}$ & $\begin{array}{l}19,58 \\
\text { (s) }\end{array}$ & $\begin{array}{l}9,91 \\
(\mathrm{sr})\end{array}$ & $\begin{array}{c}18,85 \\
(\mathrm{r})\end{array}$ \\
\hline $\begin{array}{l}\text { Peronema } \\
\text { canescens }\end{array}$ & $\begin{array}{l}4,46 \\
(\mathrm{sm})\end{array}$ & $\begin{array}{l}1,53 \\
(\mathrm{r})\end{array}$ & $\begin{array}{l}0,14 \\
(\mathrm{r})\end{array}$ & $\begin{array}{c}10,93 \\
\text { (r) }\end{array}$ & $\begin{array}{c}0,19 \\
(\mathrm{r})\end{array}$ & $\begin{array}{c}0,33 \\
(\mathrm{r})\end{array}$ & $\begin{array}{l}0,85 \\
(\mathrm{sr})\end{array}$ & $\begin{array}{c}0,55 \\
(\mathrm{r})\end{array}$ & $\begin{array}{l}16,31 \\
(\mathrm{r})\end{array}$ & $\begin{array}{c}11,77 \\
(\mathrm{sr})\end{array}$ & $\begin{array}{c}36,91 \\
(\mathrm{t})\end{array}$ \\
\hline Schima wallichii & $\begin{array}{l}4,31 \\
(\mathrm{sm}) \\
\end{array}$ & $\begin{array}{c}1,60 \\
(\mathrm{r})\end{array}$ & $\begin{array}{l}0,16 \\
(\mathrm{r})\end{array}$ & $\begin{array}{c}10,00 \\
(\mathrm{r})\end{array}$ & $\begin{array}{c}0,19 \\
(\mathrm{r}) \\
\end{array}$ & $\begin{array}{c}0,44 \\
(\mathrm{r}) \\
\end{array}$ & $\begin{array}{l}1,00 \\
(\mathrm{sr})\end{array}$ & $\begin{array}{c}0,54 \\
(\mathrm{r}) \\
\end{array}$ & $\begin{array}{c}18,49 \\
(\mathrm{~s})\end{array}$ & $\begin{array}{c}11,74 \\
(\mathrm{sr})\end{array}$ & $\begin{array}{c}29,91 \\
(\mathrm{~s})\end{array}$ \\
\hline & $\begin{array}{l}\mathrm{sm} \\
\mathrm{r} \\
\mathrm{s} \\
\mathrm{t}\end{array}$ & $\begin{array}{l}=\text { sange } \\
=\text { renda } \\
=\text { sedar } \\
=\text { tingg }\end{array}$ & 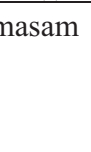 & & & & & & & & \\
\hline
\end{tabular}

Tabel (Table) 6. Koefisien korelasi antara tumbuhan bawah dengan kualitas tanah (Corelation coefficient between understorey and soil quality)

\begin{tabular}{|c|c|c|c|c|c|c|c|}
\hline Parameter & $\mathrm{pH}$ & C Org. & N-Tot & $\begin{array}{l}\mathrm{C} / \mathrm{N} \\
\text { Ratio }\end{array}$ & $\begin{array}{l}\mathrm{KTK} \\
(C E C)\end{array}$ & $\begin{array}{l}\text { Kej. Basa } \\
\text { (Base Sat.) }\end{array}$ & $\begin{array}{l}\text { Kej. Al } \\
\text { (Al Sat.) }\end{array}$ \\
\hline $\begin{array}{l}\text { Keragaman jenis } \\
\text { (Species diversity) }\end{array}$ & $-0,7202$ & $-0,9000$ & $-0,9696$ & 0,1605 & 0,5565 & $-0,1091$ & $-0,8912$ \\
\hline $\begin{array}{l}\text { Kelimpahan (Abundance) } \\
\text { Lygodium circinatum Sw. }\end{array}$ & $-0,9598^{*}$ & $-0,6978$ & $-0,7191$ & 0,1022 & 0,7397 & 0,0814 & $-0,9511$ \\
\hline $\begin{array}{l}\text { Kelimpahan (Abundance) } \\
\text { Chromolaena odorata }\end{array}$ & $-0,7123$ & $0,9852^{*}$ & $-0,8722$ & $-0,3165$ & 0,7933 & $-0,5317$ & $-0,9162$ \\
\hline $\begin{array}{l}\text { Kelimpahan (Abundance) } \\
\text { Imperata cylindrica }\end{array}$ & 0,6913 & $0,9470^{*}$ & $0,9801^{*}$ & $-0,0568$ & $-0,5911$ & 0,2312 & 0,8923 \\
\hline
\end{tabular}

Keterangan (Remarks): * = nyata (significant)

bahwa struktur dan komposisi tumbuhan bawah pada tegakan Eucalyptus berbeda dengan di lahan pertanian dan hutan sekunder, dimana perbedaan tersebut dipengaruhi oleh jenis vegetasi dan penutupan tajuk.

Jenis tanaman dengan penutupan tajuk yang berbeda akan membentuk iklim mikro yang berbeda pada lantai hutan. Sementara perbedaan kecepatan dekomposisi serasah pada tiap jenis tegakan mengakibatkan suplai bahan organik di dalam tanah juga akan berbeda, sehingga kualitas tanah pada tiap jenis tegakan juga akan berbeda. Hal ini juga akan mempengaruhi tingkat keragaman jenis tumbuhan bawah pada hutan tanaman. Berdasarkan hasil penelitian, tingkat keragaman jenis tumbuhan bawah tertinggi terdapat pada tegakan mahoni. Tegakan ini mempunyai tajuk yang lebar (rata-rata 7,58 m) sehingga mampu menciptakan lingkungan mikro seperti suhu dan kelembaban tanah yang sesuai dengan pertumbuhan berbagai jenis tumbuhan bawah, khususnya jenis-jenis yang adaptif dengan kelembaban tinggi, seperti lengkenai (Slaginella opaca) serta jenis paku-pakuan (Lygodium circinatum Sw. dan Nephrolepis biserata) (lampiran 1).

Tegakan seru tercatat mempunyai keragaman jenis tumbuhan bawah paling rendah $(0,78)$ dibandingkan dengan tegakan yang lain karena adanya dominasi alang-alang (Imperata cylindrica). Hal ini disebabkan oleh struktur tajuk tegakan seru yang kurang rapat (lebar tajuk ratarata $2,38 \mathrm{~m}$ ) sehingga menyebabkan intensitas cahaya matahari yang masuk sangat tinggi $(89,43$ $\%)$. Akibatnya jenis alang-alang tumbuh dominan dan menekan pertumbuhan vegetasi lainnya. Sedangkan jenis-jenis vegetasi lain kurang dapat berkompetisi dalam pemenuhan kebutuhan unsur hara dibandingkan dengan alang-alang. Hal ini seperti diungkapkan oleh McIlroy (1977) dalam 
Octavia et al., (2004), bahwa kelimpahan suatu jenis dipengaruhi oleh beberapa faktor seperti: persistensi (daya tahan), agresivitas (daya saing), kemampuan tumbuh kembali akibat manipulasi lahan, sifat tahan kering dan tahan dingin, penyebaran produksi musiman, kemampuan menghasilkan biji, kesuburan tanah, serta iklim terutama curah dan distribusi hujan.

Beberapa jenis tumbuhan di lokasi penelitian, seperti seru, pinus, lawatan, dan alang-alang diduga menghasilkan senyawa alelopati, yang berpengaruh pada keragaman jenis tumbuhan bawah. Seperti diungkapkan oleh Samingan (1988), bahwa jenis-jenis tersebut dapat menghasilkan senyawa kimia yang bersifat menghambat pertumbuhan individu tumbuhan lainnya. Tingkat kekerasan dari sifat penghambatan tersebut bergantung pada jenis dan iklim serta cara pengaturannyadari tumbuhan penghasil ke lingkungan, sehingga faktor-faktor lingkungan pada suatu penggunaan lahan tidak begitu menampakkan pengaruhnya. Salah satu pengaruh alelopati adalah menyebabkan akumulasi nitrogen terhambat, yang pada akhirnya akan menghambat pertumbuhan tanaman lain karena tidak dapat menyerap unsur $\mathrm{N}$ secara optimal.

\section{Kondisi lingkungan dan kualitas tanah}

Kondisi lingkungan mikro di bawah tegakan (Tabel 4) dipengaruhi oleh jenis tanaman pokok. Tegakan mahoni mempunyai percabangan yang banyak dengan tajuk yang lebat dan lebar, sehingga intensitas cahaya yang masuk di lantai hutan menjadi rendah $(61,23 \%)$. Hal ini mempengaruhi besarnya suhu dan kelembaban udara, dimana suhu udara di bawah tegakan mahoni tercatat paling rendah $\left(28,83^{\circ} \mathrm{C}\right)$ dibandingkan tegakan lainnya, dan kelembaban udara tercatat mencapai 67,90\%. Pada kondisi seperti ini, jumlah dan keragaman jenis tumbuhan bawah tercatat paling tinggi dibanding tegakan yang lain karena tidak ada satu jenis tumbuhan yang dominan dan mendesak pertumbuhan jenis-jenis tertentu. Intensitas cahaya paling tinggi tercatat pada tegakan sungkai $(91,76 \%)$, hal ini disebabkan oleh karakter tajuk dan bentuk daunnya yang tidak rapat sehingga sinar matahari dapat masuk sampai ke lantai hutan. Akibatnya suhu udara di bawah tegakan sungkai tercatat paling tinggi $\left(31,25^{\circ} \mathrm{C}\right)$ dibanding tegakan lain. Pada kondisi ini, alang-alang mampu tumbuh dominan serta menghambat jenis-jenis tumbuhan bawah yang lain.
Berdasarkan hasil analisis tanah dapat diketahui bahwa kondisi tanah di lokasi penelitian secara umum tidak subur. Hal ini diduga menjadi faktor penyebab rendahnya keragaman jenis tumbuhan bawah. Kandungan bahan organik tertinggi pada tegakan seru $(1,60)$ dan terendah pada tegakan pinus $(1,05)$. Sumber bahan organik selain berasal dari serasah juga berasal dari vegetasi tumbuhan bawah itu sendiri. Alang-alang yang mendominasi lantai tegakan seru merupakan sumber bahan organik utama karena sifatnya yang lambat terdekomposisi (Anonim, 2012; Maftuah et al., 2001). Selain itu kandungan bahan organik juga dipengaruhi oleh jenis tanaman pokok, dimana tanaman berdaun lebar akan berbeda dengan tanaman berdaun jarum (Bayer, 1956, dalam Mindawati et al., 2006). Beberapa kejadian kebakaran pada lantai hutan di areal penelitian, diduga juga berpengaruh pada kandungan unsur bahan kimia tanah.

Nitrogen $(\mathrm{N})$ merupakan unsur hara esensial yang dibutuhkan dalam jumlah banyak untuk menunjang kelangsungan pertumbuhan tanaman (Winarso, 2005). Kandungan $\mathrm{N}$ pada semua jenis tegakan termasuk dalam kategori rendah. Rendahnya kandungan $\mathrm{N}$ di dalam tanah diduga dipengaruhi oleh tidak adanya tumbuhan dari famili leguminosae yang secara alamiah mampu mengikat unsur $\mathrm{N}$ dari udara. Nilai $\mathrm{C} / \mathrm{N}$ menunjukkan tingkat pelapukan, semakin kecil nilai $\mathrm{C} / \mathrm{N}$ berarti tingkat pelapukan relatif makin tinggi. Nilai $\mathrm{C} / \mathrm{N}$ termasuk dalam kategori rendah kecuali pada tegakan mahoni yang termasuk kategori sedang $(11,36)$. Hal ini menunjukkan tingkat pelapukan pada tegakan mahoni relatif lebih rendah dibandingkan tegakan lainnya.

Ketersediaan unsur hara makro di tanah termasuk kategori sangat rendah hingga rendah, disebabkan oleh sifat tanah yang sangat masam, sehingga berdampak pada unsur hara makro. Nilai Kapasitas Tukar Kation (KTK) termasuk dalam kategori rendah hingga sedang. Makin tinggi nilai KTK pada umumnya tanah tersebut semakin subur (Mindawati et al., 2006), sehingga dapat dikatakan tanah di KHDTK Benakat tidak subur.

\section{Hubungan Keragaman Jenis Tumbuhan Bawah dengan Kualitas Tanah}

Hasil analisis korelasi antara keragaman jenis tumbuhan bawah dengan parameter kualitas tanah (Tabel 6), memperlihatkan bahwa secara umum keragaman jenis tumbuhan bawah tidak menun- 
jukkan adanya hubungan yang nyata dengan paramater kualitas tanah, kecuali $\mathrm{pH}$ untuk kelimpahan paku hata, C-Organik untuk kelimpahan katoman dan alang-alang, serta N-Total untuk kelimpahan alang-alang. Kelimpahan katoman berhubungan dengan kandungan C-Organik, semakin tinggi kandungan bahan organik maka semakin tinggi pula kelimpahan jenis katoman. Hal ini diduga karena jenis katoman merupakan tumbuhan bawah yang lambat terdekomposisi, sehingga berperan dalam meningkatkan kandungan C-organik. Kelimpahan alangalang juga mempunyai hubungan yang positif dengan kandungan C-Organikdan N-Total. Sama halnya dengan jenis katoman, alang-alang merupakan jenis tumbuhan dengan tingkat dekomposisi yang lambat.

Tidak adanya hubungan yang nyata antara keragaman jenis tumbuhan bawah dengan parameter kualitas tanah di bawah tegakan mahoni, pinus, sungkai dan seru pada penelitian ini sesuai dengan hasil penelitian Sumiyarso (1995) pada tegakan akasia di PT. Musi Hutan Persada (MHP) wilayah Gemawang, Kecamatan Rambang Dangku, Kabupaten Muara Enim yang menyatakan bahwa tidak ada hubungan yang nyata antara pertumbuhan vegetasi tumbuhan bawah dengan kualitas tanah dan perlakuan pupuk yang diberikan pada tanaman pokok. Tidak adanya hubungan antara tumbuhan bawah dengan kualitas tanah di bawah tegakan mahoni, pinus, sungkai dan seru diduga disebabkan karena kondisi tanah yang secara umumtidak subur, keragaman jenis tumbuhan bawah yang tergolong rendah (nilai $\mathrm{H}^{\prime}<2,0$ ), dan perbedaan nilai indeks keragaman pada masingmasing tegakan yang rendah.

\section{KESIMPULAN}

1. Keragaman jenis tumbuhan bawah pada tegakan mahoni, pinus, sungkai dan seru di KHDTK Benakat tergolong rendah. Keragaman jenis tumbuhan bawah tertinggi ditemukan dibawah tegakan mahoni, sedangkan terendah di bawah tegakan seru.

2. Nilai kerapatan, dominasi, dan keragaman jenis tumbuhan bawah dipengaruhi oleh jenis tanaman pokok pada hutan tanaman. Pada tegakan mahoni didominasi oleh jenis lengkenai (Slaginella opaca), pada tegakan pinus oleh rumput empritan (Crytococcum acrescens (Trin) Stapf.), sedangkan pada tegakan sungkai dan seru didominasi oleh jenis alang-alang (Imperata cylindrica L).
3. Kesuburan tanah di KHDTK Benakat tergolong rendah, dimana tidak ada hubungan yang nyata antara keragaman jenis tumbuhan bawah dengan paramater kualitas tanah, namun demikian kelimpahan katoman (Chromolaena odorata) dan alang-alang (Imperata cylindrica $L)$ pada tegakan pinus dan seru berpotensi untuk dijadikan indikator terhadap kandungan C-Organik dan N-Total.

\section{UCAPAN TERIMAKASIH}

Pada kesempatan ini penulis mengucapkan terimakasih kepada seluruh tim penelitian (Teten Rahman, Subakir, dan Yanto Chandra) yang telah membantu pekerjaan di lapangan.

\section{DAFTAR PUSTAKA}

Akbar, A., E. Priyanto, H. A. Basiang. 2005. Potensi Tanaman Revegetasi Lahan Reklamasi Bekas Tambang Batubara Dalam Mendukung Suksesi Alam. Jurnal Penelitian Hutan Tanaman: Volume 2 No.3; Halaman 131-140, 2005. Pusat Litbang Hutan Tanaman. Badan Litbang Kehutanan. Bogor.

Anonim.2012. Apa yang Buruk Dari Alang-alang? www.rerumputan221.blogspot. com. Diakses tanggal 5 Agustus 2012.

Asdak, C. 2002. Hidrologi dan Pengelolaan Daerah Aliran Sungai. Gadjah Mada University Press. Yogyakarta.

Djarwaningsih.2010. Karakterisasi Tipe Vegetasi dan Keanekaragaman Jenis Flora/Jamur di Cagar Alam Gunung Tukung Gede, Serang-Banten. Laporan Akhir Program Insentif Peneliti dan Perekayasa LIPI Tahun 2010. Tidak diterbitkan.

Indriyanto. 2006. Ekologi Hutan. PT. Bumi Aksara, Jakarta.

Maftuah E., E. Arisoesilaningsih, dan E. Handayanto. 2002. Studi Potensi Diversitas Makrofauna Tanah Sebagai Bioindikator Kualitas Tanah Pada Beberapa Penggunaan Lahan. BIODIN, Vol. 2, Agustus 2002.

Mindawati, N., A. S. Kosasih dan Y. Heryati. 2006. Pengaruh Penanaman Beberapa Jenis Pohon Hutan terhadap Kondisi Kesuburan Tanah Andosol. Jurnal Penelitian Hutan Tanaman Vol. 3 No. 3, Juni 2006. Pusat Litbang Hutan Tanaman. Badan Litbang Kehutanan. Bogor.

Odum, E. P. 1971. Fundamentals of Ecology, $3^{\text {rd }}$ Ed. Saunders, Philadelphia. 
Octavia. D., F. Azwar, M. A. Qirom., danS. Andriyani. 2004. Potensi Pakan Banteng (Bos javanicus d'Alton) di Areal Savana Seksi Wilayah Bekol Taman Nasional Baluran. Laporan Kegiatan. Balai Taman Nasional Baluran. Departemen Kehutan-an. (Tidak diterbitkan).

Pusat Penelitian Tanah. 1982. Term of Reference Type A, Klasifikasi Kesesuaian Lahan Proyek Penelitian Menunjang Transmigrasi. Bogor.

Sadili, A. 2010. Struktur dan Komposisi Jenis Tumbuhan Herba dan Semai Pada Habitat Satwa Herbivor di Suaka Margasatwa Cikepuh, Sukabumi, Jawa Barat. Jurnal Berita Biologi 10 (1)-April 2010. LIPI.

Samingan, T. 1998. Metode Analisis dan Penilaian Vegetasi. Laboratorium Ekologi. Jurusan Biologi Fakultas MIPA. Institut Pertanian Bogor. Bogor.

Schmidt, F.H and J.H.A. Ferguson. 1951. Rainfall Types Based on Wet and Dry Period Ratios for
Indonesia with Western New Guinea, Verhand No 42. Djawatan Metereologi dan Geofisika. Jakarta.

Soeranegara. I dan Indrawan. 1998. Ekologi Hutan Indonesia. Laboratorium Ekologi Hutan. Fakultas Kehutanan. Institut Pertanian Bogor. Bogor.

Sumiyarso. 1995. Studi Komposisi dan Struktur Vegetasi Tumbuhan Bawah Tegakan Acacia mangium. Tesis Pascasarjana Universitas Gajah Mada, Yogyakarta. (Tidak diterbitkan).

Wang Hua-Feng, M. Lencinas, C. R. Friedman, X. Wang, J. Qiu. 2010. Understory Plant Diversity Assesment of Eucalyptus Plantations Over Three Vegetation Types in Yunnan, China. Online Journal.Springer Science + Business Media B.V.

Winarso, S. 2005. Kesuburan Tanah. Dasar Kesehatan dan Kualitas Tanah. Penerbit Gava Media. Yogyakarta. 
Lampiran (Appendix)1. Jenis-jenis tumbuhan bawah pada tegakan mahoni (Understorey species on the Sweitenia macrophylla stand)

\begin{tabular}{|c|c|c|c|c|c|c|}
\hline No. & $\begin{array}{l}\text { Nama Famili } \\
\text { (Family name) }\end{array}$ & No & $\begin{array}{l}\text { Nama Lokal } \\
\text { (Local name) }\end{array}$ & $\begin{array}{l}\text { Nama Latin } \\
\text { (scientific name) }\end{array}$ & $\begin{array}{l}\text { INP } \\
(I V I)\end{array}$ & $\mathrm{H}$ \\
\hline 1 & Amarillidaceae & 1 & Paleman & Curuligo orchoides & 1,33 & 0,01 \\
\hline 2 & Araceae & 2 & Keladi hutan & Colocasia sp. & 1,33 & 0,01 \\
\hline \multirow[t]{2}{*}{3} & \multirow[t]{2}{*}{ Asteraceae } & 3 & Calincing & Ageratum swaviolens & 2,65 & 0,02 \\
\hline & & 4 & Katoman & $\begin{array}{l}\text { Chromolaena odorata (L.) } \\
\text { R.M. King \& H. Robinson }\end{array}$ & 24,21 & 0,11 \\
\hline \multirow[t]{2}{*}{4} & \multirow[t]{2}{*}{ Compositae } & 5 & Jelentir & Erigeron sumatraensis Retz & 2,40 & 0,02 \\
\hline & & 6 & Lawatan & Mikania micrantha H.B.K. & 2,86 & 0,03 \\
\hline 5 & Cyaperaceae & 7 & Belidang & Scleria sumatrensis Retz & 4,19 & 0,04 \\
\hline \multirow[t]{2}{*}{6} & \multirow[t]{2}{*}{ Euphorbiaceae } & 8 & Katukan & Sauropus androgymus Merr & 1,33 & 0,01 \\
\hline & & 9 & Meniran & Phyllanthus niruri L. & 9,11 & 0,06 \\
\hline \multirow[t]{2}{*}{7} & \multirow[t]{2}{*}{ Graminae } & 10 & Empritan & $\begin{array}{l}\text { Cyrtococcum acrescens (Trin) } \\
\text { Stapf }\end{array}$ & 3,08 & 0,03 \\
\hline & & 11 & $\begin{array}{l}\text { Jampang } \\
\text { kerincing }\end{array}$ & $\begin{array}{l}\text { Oplismenus compositus (L.) } \\
\text { Beauv }\end{array}$ & 6,80 & 0,05 \\
\hline 8 & Leeaceae & 12 & Girang & Leea indica (Burm.f.) Merr. & 1,54 & 0,02 \\
\hline 9 & Maranthaceae & 13 & - & Stachyphynium sp. & 13,10 & 0,08 \\
\hline 10 & Musaceae & 14 & Pisang hutan & Musa acuminata Colla & 1,54 & 0,02 \\
\hline 11 & Myrsinaceae & 15 & Pisang hutan & Maesa $s p$ & 9,70 & 0,06 \\
\hline 12 & Myrtaceae & 16 & Salam & $\begin{array}{l}\text { Syzygium of, Fastigiatum } \\
\text { (Blume) Merr. \& Perry }\end{array}$ & 3,29 & 0,03 \\
\hline 13 & Neprolepidaceae & 17 & Paku harupat & Nephrolepis biserata & 22,17 & 0,11 \\
\hline 14 & Piperaceae & 18 & Krokot & Peperomia pellucida $\mathrm{K}$ th & 3,72 & 0,03 \\
\hline 15 & Rubiaceae & 19 & Simpur gajah & Randia Pantula Mig & 1,33 & 0,01 \\
\hline 16 & Rutaceae & 20 & Tikusan & Clausena of, excavata & 1,54 & 0,02 \\
\hline 17 & Schizaeaceae & 21 & Paku hata & Lygodium circinatum $\mathrm{Sw}$. & 24,76 & 0,11 \\
\hline 18 & Selaginellaceae & 22 & Lengkenai & Slaginella opaca & 47,46 & 0,15 \\
\hline 19 & Simaroubaceae & 23 & Puding hutan & Chasalia curviflora Thwaites & 2,18 & 0,02 \\
\hline 20 & Solanceae & 24 & Terung hutan & Solanum sp. & 1,75 & 0,02 \\
\hline \multirow[t]{2}{*}{21} & Zingiberaceae & 25 & Temulawak & Curcuma sp. & 3,98 & 0,03 \\
\hline & Total & & & & & 1,11 \\
\hline
\end{tabular}


Lampiran (Appendix) 2. Jenis-jenis tumbuhan bawah pada tegakan pinus (Understorey species on the Pinus merkusii stand)

\begin{tabular}{|c|c|c|c|c|c|c|}
\hline No & $\begin{array}{l}\text { Nama Famili } \\
\text { (Family name) }\end{array}$ & No & $\begin{array}{l}\text { Nama Lokal } \\
\text { (Local name) }\end{array}$ & $\begin{array}{l}\text { Nama Latin } \\
\text { (scientific name) }\end{array}$ & $\begin{array}{l}\text { INP } \\
(I V I)\end{array}$ & $\mathrm{H}$ \\
\hline 1 & Amarillidaeceae & 1 & Paleman & Curuligo orchoides Gaertn & 4,53 & 0,04 \\
\hline 2 & Apocynaceae & 2 & Gakeman wajit & Paraneria sp. & 1,40 & 0,02 \\
\hline \multirow[t]{2}{*}{3} & Asteraceae & 3 & Bandotan & Ageratum conyzoides & 1,60 & 0,02 \\
\hline & & 4 & Katoman & $\begin{array}{l}\text { Chromolaena odorata (L.) R. } \\
\text { M. King \& H. Robinson }\end{array}$ & 30,67 & 0,12 \\
\hline \multirow[t]{4}{*}{4} & Compositae & 5 & Jelentir & Erigeron sumatraensis Retz & 2,51 & 0,02 \\
\hline & & 6 & Lawatan & Mikania micrantha & 3,00 & 0,03 \\
\hline & & 7 & Sintrong & $\begin{array}{l}\text { Erechtites valeriafolia (Wolf) } \\
\text { DC }\end{array}$ & 0,70 & 0,01 \\
\hline & & 8 & Tembelekan & Lantanan camara Linn & 0,70 & 0,01 \\
\hline 5 & Cyaperaceae & 9 & Belidang & Scleria sumatrensis Retz & 7,33 & 0,05 \\
\hline \multirow[t]{4}{*}{6} & Euphorbiaceae & 10 & Katukan & Sauropus androgymus Merr & 0,90 & 0,01 \\
\hline & & 11 & Meniran & Phyllanthus niruri $\mathrm{L}$. & 25,12 & 0,11 \\
\hline & & 12 & Daun kapur & $\begin{array}{l}\text { Mallotus peltatus (Geisel,) } \\
\text { Muell, Arg }\end{array}$ & 2,94 & 0,03 \\
\hline & & 13 & Patikan & Euphorbia hirta & 2,07 & 0,02 \\
\hline \multirow[t]{3}{*}{7} & Graminae & 14 & Empritan & $\begin{array}{l}\text { Cyrtococcum acrescens (Trin) } \\
\text { Stapf }\end{array}$ & 56,18 & 0,15 \\
\hline & & 15 & $\begin{array}{l}\text { Jampang } \\
\text { kerincing }\end{array}$ & $\begin{array}{l}\text { Oplismenus compositus (L) } \\
\text { Beauv }\end{array}$ & 0,84 & 0,01 \\
\hline & & 16 & Paitan & Paspalum conjugatun Berg & 0,70 & 0,01 \\
\hline 8 & Labiateae & 17 & Cungit & Hyptis rhomboidea Mart \& Gal & 4,85 & 0,04 \\
\hline 9 & Leeaceae & 18 & Girang & Leea indica (Burm.f.) Merr. & 2,80 & 0,03 \\
\hline \multirow[t]{2}{*}{10} & Melastomaceae & 19 & Harendong & Clidemia hirta DON & 5,78 & 0,04 \\
\hline & & 20 & Seduduk & Melastoma candidum D. Don & 2,10 & 0,02 \\
\hline 11 & Piperaceae & 21 & Krokot & Peperomia pellucida Ktl & 3,02 & 0,03 \\
\hline 12 & Schizaeaceae & 22 & Paku hata & Lygodium circinatum $\mathrm{Sw}$. & 19,60 & 0,10 \\
\hline 13 & Selaginellaceae & 23 & Lengkenai & Selaginella opaca & 6,32 & 0,05 \\
\hline 14 & Solanaceae & 24 & Terung hutan & Solanum toruum & 10,55 & 0,07 \\
\hline \multirow[t]{2}{*}{15} & Verbenaceae & 25 & Jarongan & Stachytarpheta indica (L.) Vahl & 3,81 & 0,03 \\
\hline & Total & & & & & 1,06 \\
\hline
\end{tabular}


Lampiran (Appendix) 3. Jenis-jenis tumbuhan bawah pada tegakan sungkai (Understorey species on the Peronema canescens stand)

\begin{tabular}{|c|c|c|c|c|c|c|}
\hline No. & $\begin{array}{l}\text { Nama Famili } \\
\text { (Family name) }\end{array}$ & No & $\begin{array}{l}\text { Nama Lokal } \\
\text { (Local name) }\end{array}$ & $\begin{array}{c}\text { Nama Latin } \\
\text { (scientific name) }\end{array}$ & $\begin{array}{l}\text { INP } \\
(I V I)\end{array}$ & $\mathrm{H}$ \\
\hline 1 & Asteraceae & 1 & Katoman & $\begin{array}{l}\text { Chromolaena odorata }(\mathrm{L}) \text {. R. } \\
\text { M. King \& H. Robinson }\end{array}$ & 13,22 & 0,08 \\
\hline \multirow[t]{3}{*}{2} & \multirow[t]{3}{*}{ Compositae } & 2 & Lawatan & Mikania micrantha & 0,78 & 0,01 \\
\hline & & 3 & Sintrong & $\begin{array}{l}\text { Erechtites valeriafolia (Wolf) } \\
\text { DC }\end{array}$ & 0,74 & 0,01 \\
\hline & & 4 & Tembelakan & Lantana camara Linn & 3,82 & 0,03 \\
\hline 3 & Convolvulaceae & 5 & Kangkungan & Merremia peltata Merr. & 0,74 & 0,01 \\
\hline 4 & Cyaperaceae & 6 & Belidang & Scleria sumatrensis Retz & 4,28 & 0,04 \\
\hline \multirow[t]{2}{*}{5} & \multirow[t]{2}{*}{ Euphorbiaceae } & 7 & Meniran & Phyllanthus niruri $\mathrm{L}$. & 2,94 & 0,03 \\
\hline & & 8 & Patikan & Euphorbia hirta & 2,39 & 0,02 \\
\hline 6 & Gleicheniaceae & 9 & Resam & Gleichenia linearis Clark & 1,20 & 0,01 \\
\hline \multirow[t]{4}{*}{7} & \multirow[t]{4}{*}{ Graminae } & 10 & Alang-alang & Imperata cylindrica $\mathrm{L}$. & 80,38 & 0,16 \\
\hline & & 11 & Empritan & $\begin{array}{l}\text { Cyrtococcum acrescens (Trin) } \\
\text { Stapf }\end{array}$ & 20,99 & 0,10 \\
\hline & & 12 & Kretekan & $\begin{array}{l}\text { Cyrtococcum oxyphyllum } \\
\text { (Hoechst. ex Steud) }\end{array}$ & 1,47 & 0,02 \\
\hline & & 13 & - & Paspalum conjugatum Berg & 3,36 & 0,03 \\
\hline 8 & Labiateae & 14 & Cungit & Hyptis rhomboidea Mart \& Gal & 1,52 & 0,02 \\
\hline 9 & Leeaceae & 15 & Girang & Leea indica (Burm.f.) Merr. & 3,86 & 0,03 \\
\hline 10 & Melastomaceae & 16 & Seduduk & Melastoma candidum D. Don & 3,45 & 0,03 \\
\hline 11 & Mimosaceae & 17 & Putri malu & $\begin{array}{l}\text { Mimosa pudica L. } \\
\text { Ludwigia hyssophyfolia }\end{array}$ & 0,83 & 0,01 \\
\hline 12 & Onagaceae & 18 & Gondang & $\begin{array}{l}\text { (G.Don.) Exell apud A. \& R. } \\
\text { Fernandes }\end{array}$ & 1,47 & 0,02 \\
\hline 13 & Rubiaceae & 19 & Tenam betul & Psychotria secundiflora Val & 3,50 & 0,03 \\
\hline 14 & Rutaceae & 20 & Tikusan & Clausena of, excavata & 0,74 & 0,01 \\
\hline 15 & Schizaeaceae & 21 & Paku hata & Lygodium circinatum $\mathrm{Sw}$. & 8,47 & 0,06 \\
\hline 16 & Selaginellaceae & 22 & Lengkenai & Selaginella opaca & 2,25 & 0,02 \\
\hline 17 & Solanaceae & 23 & Terung hutan & Solanum sp. & 3,08 & 0,03 \\
\hline \multirow[t]{2}{*}{18} & Verbenaceae & 24 & Jarongan & Stachytarpheta indica (L.) Vahl & 3,04 & 0,03 \\
\hline & Total & & & & & 0,83 \\
\hline
\end{tabular}


Lampiran (Appendix) 4. Jenis-jenis tumbuhan bawah pada tegakan seru (Understorey species on the Schima wallichii stand)

\begin{tabular}{|c|c|c|c|c|c|c|}
\hline No & $\begin{array}{l}\text { Nama Famili } \\
\text { (Family name) }\end{array}$ & No & $\begin{array}{l}\text { Nama Lokal } \\
\text { (Local name) }\end{array}$ & $\begin{array}{l}\text { Nama Latin } \\
\text { (scientific name) }\end{array}$ & $\begin{array}{l}\text { INP } \\
(I V I)\end{array}$ & $\mathrm{H}$ \\
\hline 1 & Amarillidaceae & 1 & Paleman & Curuligo orchoides & 5,38 & 0,04 \\
\hline 2 & Asteraceae & 2 & Katoman & $\begin{array}{l}\text { Chromolaena odorata (L). R. } \\
\text { M. King \& H. Robinson }\end{array}$ & 14,44 & 0,08 \\
\hline \multirow[t]{2}{*}{3} & \multirow[t]{2}{*}{ Compositae } & 3 & Lawatan & Mikania micrantha H.B.K & 1,68 & 0,02 \\
\hline & & 4 & Tembelakan & Lantana camara Linn & 0,78 & 0,01 \\
\hline 4 & Cyaperaceae & 5 & Belidang & Scleria sumatrensis Retz & 17,98 & 0,09 \\
\hline \multirow[t]{4}{*}{5} & \multirow[t]{4}{*}{ Euphorbiaceae } & 6 & Gandri & Bridelia tomentosa Blume & 5,33 & 0,04 \\
\hline & & 7 & Katukan & Sauropus androgymus Merr & 0,78 & 0,01 \\
\hline & & 8 & Meniran & Phyllantus niruri $\mathrm{L}$. & 4,81 & 0,04 \\
\hline & & 9 & Patikan & Euphorbia hirta & 1,50 & 0,02 \\
\hline \multirow[t]{4}{*}{6} & \multirow[t]{4}{*}{ Graminae } & 10 & Alang-alang & Imperata cylindrica (Linn) & 98,14 & 0,15 \\
\hline & & 11 & Empritan & $\begin{array}{l}\text { Cyrtococcum acrescens (Trin) } \\
\text { Stapf }\end{array}$ & 3,34 & 0,03 \\
\hline & & 12 & $\begin{array}{l}\text { Jampang } \\
\text { kerincing }\end{array}$ & $\begin{array}{l}\text { Oplismenus compositus (L) } \\
\text { Beauv }\end{array}$ & 0,85 & 0,01 \\
\hline & & 13 & Paitan & Paspalum conjugathun Berg & 5,05 & 0,04 \\
\hline 7 & Labiateae & 14 & Cungit & Hyptis rhomboidea Mart \& Gal & 0,75 & 0,01 \\
\hline 8 & Melastomaseae & 15 & Seduduk & Melastoma candidum D. Don & 1,50 & 0,02 \\
\hline 9 & Mimosaceae & 16 & Puri malu & Mimosa pudica Linn & 3,86 & 0,03 \\
\hline 10 & Schizaeaceae & 17 & Paku hata & Lygodium circinatum $\mathrm{Sw}$. & 14,46 & 0,08 \\
\hline 11 & Selaginellaceae & 18 & Lengkenai & Selaginella opaca & 1,60 & 0,02 \\
\hline 12 & Smilaxaceae & 19 & Gadung duri & Smilax zeylenica L. & 0,75 & 0,01 \\
\hline 13 & Solanaceae & 20 & Terung hutan & Solanum sp. & 0,78 & 0,01 \\
\hline \multirow[t]{2}{*}{14} & Verbenaceae & 21 & Jarongan & Stachtarpheta indica (L.) Vahl & 150 & 002 \\
\hline & Total & & & & & 0,78 \\
\hline
\end{tabular}

